\title{
Pengembangan Kurikulum Pencak Silat Berbasis Kerangka Kualifikasi Nasional Indonesia
}

\author{
Suandi Selian* \& Dodi Irwansyah \\ Program Studi Olahraga, Fakultas Keguruan dan Ilmu Pendidikan, \\ Universitas Samudra Langsa, Indonesia
}

Diterima: Oktober 2018; Disetujui: Oktober 2018; Dipublish: Oktober 2018

*Email: soeandieselly@ymail.com

\begin{abstract}
Abstrak
Penelitian ini bertujuan untuk menemukan pengembangan kurikulum pencak silat berbasis Kerangka Kualifikasi Nasional Indonesia, Target khusus pada tahapan pertama ini yaitu dapat menganalisis kebutuhan kurikulum pencak silat dan terbentuknya draf kurikulum pencak silat berbasis Kerangka Kualifikasi Nasional Indonesia dan juga berdasarkan kompetensi yang diharapkan dari Permenpan RB. Metodologi Penelitian yang digunakan yaitu penelitian pengembangan (R\&D) Borg \& Gall. yang menjadi Sampel pada penelitian ini adalah Mahasiswa dan Dosen Mata Kuliah Pencak Silat di Prodi Olahraga Universitas Samudra Langsa. Berdasarkan tujuan penelitian, untuk membentuk lulusan yang memiliki kompetensi untuk menjadi guru profesional pada bidang studi pencak silat sehingga dapat bersaing dengan lulusan baik dari dalam negeri maupun luar negeri. Pada Tahap Pertama direncanakan kegiatan berupa observasi, wawancara dan studi banding ke Prodi yang sudah menjalankan kurikulum berbasis Kerangka Kualifikasi Nasional Indonesia, dan menghasilkan kerangka draf kurikulum. Selanjutnya pada tahap kedua berdasarkan dari hasil kerangka draf dilakukan Focus Group Discussion pada para pakar kurikulum, pakar pencak silat dan dosen Kelompok Dosen Bidang Keahlian pencak silat sehingga terbentuknya kurikulum yang telah divalidasi, pada tahap ketiga dilakukan uji coba pada mahasiswa Program Studi Olahraga, Fakultas Keguruan dan Ilmu Pendidikan, Universitas Samudra Langsa dan di evaluasi.
\end{abstract}

Kata Kunci : Pengembangan Kurikulum, Pencak Silat, Kerangka Kualifikasi Nasional Indonesia

\section{Abstract}

This study aims to find the development of the pencak silat curriculum based on the Indonesian National Qualifications Framework, the specific target at this first stage is to analyze the needs of the pencak silat curriculum and the formation of the pencak silat curriculum based on the Indonesian National Qualifications Framework and also based on the competencies expected from Permenpan RB. The research methodology used was the development research (R\&D) Borg \& Gall. the sample in this study were students and lecturers of Pencak Silat course at the Sports Study Program of Universitas Samudra Langsa. Based on the research objectives, to form graduates who have the competence to become professional teachers in the field of martial arts studies so that they can compete with graduates both from domestic and abroad. In the First Stage planned activities in the form of observation, interviews and comparative studies to study programs that have run the Indonesian National Qualifications Framework based curriculum, and produce a draft curriculum framework. Then in the second phase based on the results of the draft drafts conducted Focus Group Discussion on curriculum experts, pencak silat experts and lecturers in the field of Pencak Silat Expertise Field so that the formation of a validated curriculum, in the third stage a trial was conducted for Sports Study Program students, Teaching Faculty and Education Sciences, Universitas Samudra Langsa and evaluated.

Keywords: Curriculum Development, Pencak Silat, Indonesian National Qualification Framework

How to Cite: Selian, S. \& Irwansyah, D. (2018). Pengembangan Kurikulum Pencak Silat Berbasis Kerangka Kualifikasi Nasional Indonesia. Journal of Education, Humaniora and Social Sciences (JEHSS). 1 (1): 32-39..

\section{PENDAHULUAN}

Perkembangan olahraga sekarang ini sudah semakin maju dan modern. Sehingga menjadikan olahraga tidak luput dari perhatian semua pihak, tidak terkecuali di Indonesia perkembangan olahraga ini sudah sejak lama menjadi perhatian pemerintah. Indonesia yang berhasil meraih Juara umum pada Sea Games Tahun 2012 menurun peringkat nya pada Sea Games di Qatar tahun 2014 dan Sea Games di Singapore tahun 2016. Yang lebih menjadi perhatian lagi adalah penurunan prestasi ini tidak saja terjadi pada satu cabang olahraga, akan tetapi hampir pada semua cabang olahraga. Untuk menyikapi hal tersebut pemerintah terus berusaha memperbaiki prestasi olahraga Indonesia untuk kedepannya. Ini terlihat dari program-program yang dilakukan pemerintah untuk melakukan pembinaan sejak dini baik terhadap atlet dan juga pelatih, salah satunya adalah memberikan uang pebinaan dan pelatihan-pelatihan kepada pelatih muda untuk nanti bisa mengembangkan karirnya sebagai pelatih. 
Tidak hanya terlepas dari permasalahan tersebut, perguruan tinggi yang memiliki jurusan dalam hal keguruan tidak mempunyai kurikilum yang mendukung bagaimana untuk menjadi seorang guru. Sebagaimana visi jurusan Pendidikan Olahraga Universitas Samudra yaitu mewujudkan jurusan Pendidikan Olahraga yang unggul dalam bidang guru pendidikan jasmani serta kemampuan manajerial untuk menghasilkan prestasi unggul secara profesional. Berdasarkan kurikulum blok yang dipakai di jurusan Pendidikan Olahraga, mahasiswa diajarkan bagaimana menjadi seorang guru sehingga penerapan ilmu keguruan tidak semuanya terealisasikan kepada mahasiswa.

Sistem pendidikan untuk keguruan pada jurusan Pendidikan Olahraga tidak berjalan sesuai yang diharapkan, karena setelah mahasiswa menyelesaikan perkuliahan, dan melamar pekerjaan menjadi guru Pegawai Negeri Sipil, di Nangroeh Aceh Darussalam khususnya banyak daerah yang tidak menerima jurusan keguruan untuk dijadikan sebagai tenaga pelatih dengan alasan bahwa lulusan dari jurusan keguruaan dan ilmu pendidikan bukanlah seorang pelatih tetapi guru. Sehingga banyak sekali alumni keguruan yang tidak memiliki pekerjaan dikarenakan keterbatasan pengetahuan untuk menjadi seorang guru.

Untuk menyikapi keterbatasan lapangan pekerjaan pada alumni keguruan. Pemerintah membuat suatu kebijakan dengan mengeluarkan Peraturan Pemerintah No. 40 tahun 2014 tanggal 16 Oktober 2016 tentang jabatan fungsional pelatih dan No.41 tahun 2014 tanggal 16 Oktober 2016 tentang jabatan fungsional asisten pelatih. Hal ini untuk mendukung prestasi olahrga di Indonesia baik nasional maupun internasional, serta untuk meningkatkan kinerja organisasi perlu ditetapkan jabatan fungsional pelatih olahraga. Keluarnya Peraturan pemerintah tahun 2014 sejalan dengan program yang dikeluarkan oleh Kerangka Kualifikasi Nasional Indonesia (KKNI). Dengan adanya program yang dikeluarkan Kerangka Kualifikasi Nasional Indonesia (KKNI) dan peraturan pemerintah profesi kepelatihan semakin diperhatikan dan semakin sejahtera sehingga diharapkan mampu untuk menunjang prestasi olahraga di Indonesia.

Keluarnya peraturan dari Kerangka Kualifikasi Nasional Indonesia (KKNI) mengharuskan perguruan tinggi mengubah kurikulum yang sudah ada dengan kurikulum yang ditetapkan dengan standard Kerangka Kualifikasi Nasional Indonesia (KKNI) yang memiliki peraturan yang harus disesuaikan dengan kebutuhan daerah masing-masing. Di Universitas Samudra Langsa khususnya Jurusan Pendidikan Olahraga memiliki kurikulum yang lebih mengarahkan mahasiswa kepada profesi pelatih bukan guru. Dengan demikian untuk menyesuaikan kebutuhan di lapangan pihak Program Studi harus bisa menyesuaikan kurikulum yang lama sesuai dengan apa yang ditetapkan oleh Kerangka Kualifikasi Nasional Indonesia.

Contoh kecilnya bisa kita lihat pada mata kuliah pencak silat di jurusan Pendidikan Olahraga Universitas Samudra Langsa dimana pada saat perkuliahan mahasiswa hanya dituntut untuk dapat mengajarkan tehnik yang ada dalam pencak silat kepada peserta didik. Bukan dipersiapkan bagaimana mahasiswa untuk bisa menjadi pelatih pencak silat. Hal ini dikarenakan kurikulum yang dipakai adalah KBK Blog dan Pedidikan Olahraga di Universitas Samudra masih lebih memfokuskan mahasiswa untuk menjadi guru. Dengan keluarnya peraturan dari Kerangka Kualifikasi Nasional Indonesia (KKNI) maka Program Studi harus serius menyikapi dan menyiapkan kurikilum baru yang merujuk kepada kompetensi yang harus dimiliki oleh seorang pelatih.

Dengan perubahan kurikulum maka prodi harus lebih meningkatkan kinerja dan sumberdaya dosen dan fasilitas-fasilitas yang menjadi penunjang untuk perkuliahan. Dengan keluarnya peraturan dari Kerangka Kualifikasi Nasional Indonesia (KKNI) maka Prodi harus serius menyikapi dan menyesuaikan perubahan kurikilum baru yang merujuk kepada kompetensi yang harus dimiliki oleh seorang pelatih. Keluarnya Peraturan Pemerintah ini, menuntut dosen agar lebih serius untuk mengetahui apa saja yang dibutuhkan oleh mahasiswa kepelatihan untuk menjadi pelatih yang profesional, khususnya untuk menjadi pelatih pencak silat profesional. Adapun hal yang paling utama yang harus diperhatikan dosen adalah Pengetahuan filosofi melatih, Mengetahui bagaimana tentang ilmu psikologi kepelatihan, Mengetahui dasar-dasar ilmu kepelatihan, Mengetahui tentang ilmu fisiologi dan ilmu gizi dan Pengalaman melatih.

Termasuk pelatih pencak silat. Untuk menyikapi hal tersebut prodi harus benar-benar serius menyikapi bagaimana penataan perkuliahan dan penetapan mata kuliah dan juga standar kelulusan yang akan dikeluarkan untuk mahasiswa, sehingga menjadi lulusan yang dapat bersaing dan memiliki kemampuan yang diharapkan.

\section{METODE PENELITIAN}

Penelitian ini akan dilaksanakan di Fakultas Keguruan dan Ilmu Pendidikan Universitas Samudra khususnya Prodi Olahraga. Untuk melakukan analisis kebutuhan dilakukan observasi ke beberapa dosen pengampu serta mahasiswa mata kuliah pencak silat.

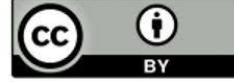

This work is licensed under a Creative Commons Attribution 4.0 
DOI: $\underline{\text { https://doi.org/10.34007/iehss.v1i1.5 }}$

Penelitian ini menggunakan pendekatan reseach and depelopment atau pengembangan. Penelitian ini diawali dengan analisis kebutuhan dari pengguna sebagai bahan untuk melakukan redesain kurikulum (GBPP/silabus). Dilanjutkan dengan mengumpulkan bahan untuk menyusun materi perkuliahan dan kontrak perkuliahan.

Penelitian ini dilakukan untuk menghasilkan produk silabus dan kontrak perkuliahan pencak silat. Secara keseluruhan kegiatan ini dilaksanakan dala tiga tahap, yaitu: tahap analisis kurikulum dan identifikasi buku kuliah, tahap uji coba buku, serta tahap evaluasi dan penyempurnaan buku. Ketiga tahapan ini merupakan bagian yang tak terpisahkan dari suatu siklus pengembangan. Berikut secara rinci kegiatan dari setiap siklus yang dilakukan.

Tahap pertama, dilakukan persiapan untuk melakukan wawancara dan observasi. Kemudian analisis pendahuluan, analisis mahasiswa, analisis materi, analisis tugas dan kebutuhan yang disebut masalah dasar dan pengembangannya. Analisis kebutuhan ini dilakukan untuk menemukan kurikulum pembelajaran berbasis Kerangka Kualifikasi Nasional Indonesia (KKNI) dan Peraturan Menteri Nomor 40 dan 41 Tahun 2014. Data penelitian dikumpulkan dari Universitas Samudra Langsa dan Universitas Negeri Medan. Yaitu pada Universitas Samudra Langsa merupakan Universitas yang memakai kurikulum KBK Blok dan Universitas Negeri Yogjakarta sebagai universitas pembanding yang telah melaksanakan Kurikulum Berbasis Kerangka Kualifikasi Nasional Indonesia (KKNI). Kemudian mengidentifikasi draft kurikulum berdasarkan Kerangka Kualifikasi Nasional Indonesia (KKNI) dan Peraturan Menteri.

Data untuk tahap pertama penelitian ini diperoleh dari berbagai teknik pengukuran, seperti observasi lapangan (pelaksanaan proses pembelajaran), dokumentasi (materi ajar) serta wawancara mendalam dengan dosen mata kuliah pencak silat, ketua prodi Pendidikan Olahraga Universitas Samudra Langsa, beberapa Pengurus Provinsi Persatuan Pencak Silat Nangroeh Aceh Darussalam dan studi banding ke Universitas Negeri Jakarta. Analisis dilakukan dengan melihat kebutuhan kesesuaian kurikulum KBK Blok dengan Kurikulum Berbasis Kerangka Kualifikasi Nasional Indonesia dan Permen Nomor 40 dan 41 Tahun 2014.

Tahap kedua draft kurikulum telah disusun dan sekaligus sebagai bahan masukan untuk revisi tahap awal, serta melakukan FGD kepada para ahli/pakar pencak silat. Pada tahap kedua ini setelah melakukan FGD maka kurikulum akan di validasi sehingga perangkat kurikulum telah selesai dan siap untuk diuji cobakan.

Data penelitian untuk tahap II ini diperoleh dari catatan dosen dan mahasiswa, wawancara dan lembar observasi. Catatan dosen digunakan untuk melihat kurikulum yang selama ini diberlakukan. Sedangkan wawacara dan lembar observasi untuk melihat apakah kurikulum berbasis KKNI dan Peraturan Pemerintah sangat bermanfaat bagi jurusan Pendidikan Olahraga Universitas Samudra Langsa.

Tahap ketiga melakukan uji coba kurikulum pencak silat berbasis Kerangka Kualifikasi Nasional Indonesia (KKNI) dalam bentuk Rencana Perkuliahan Semester (RPS). Sebelum uji coba dilakukan di kampus, uji coba kurikulum dalam skala kecil akan dilakukan. Rencana Perkuliahan Semester (RPS) akan dibaca dan dipelajari oleh beberapa mahasiswa dan dosen yang bukan tim peneliti. Perbaikan Rencana Perkuliahan Semester (RPS) akan dilakukan berdasarkan masukan-masukan dalam uji coba skala kecil. Selanjutnya kegiatan uji coba Rencana Perkuliahan Semester (RPS) akan dilaksanakan di kampus di kelas yang telah ditentukan, diantaranya kelas yang masuk mata kuliah pencak silat. Kemudian melakukan evaluasi terhadap kurikulum yang sudah diuji cobakan. Setelah dievaluasi kurikulum diperkenalkan pada forum Kelompok Dosen Bidang Keahlian (KDBK). Berdasarkan model pendekatan yang telah diuraikan maka tahap kegiatan dalam penelitian dapat digambarkan sebagai berikut:

\begin{tabular}{|c|c|c|c|}
\hline Tahap 1 & & Tahap 2 & Tahap 3 \\
\hline $\begin{array}{l}\text { 1. Persiapan } \\
\text { 2. Analisis masalah } \\
\text { dasar } \\
\text { 3. Studi banding }\end{array}$ & & $\begin{array}{c}\text { 1. Rancangan Perangkat } \\
\text { 2. Melakukan FGD } \\
\text { 3. Evaluasi } \\
\text { 4. Validasi }\end{array}$ & $\begin{array}{l}\text { 1. Ujicoba Kurikulum } \\
\text { 2. Evaluasi } \\
\text { 3. Forum KDBK }\end{array}$ \\
\hline $\begin{array}{l}\text { 1. Dosen } \\
\text { 2. Mahasiswa }\end{array}$ & $\begin{array}{c}\text { Hasil: } \\
\text { 1.Draft Kurikulum } \\
\text { 2. Draft Perangkat } \\
\text { Perkuliahan }\end{array}$ & $\begin{array}{l}\text { Hasil : } \\
\text { 1. Kurikulum Pencak } \\
\text { Silat Berbasis KKNI }\end{array}$ & $\begin{array}{l}\text { Hasil : } \\
\text { 1. Kurikulum Pencak Silat } \\
\text { berbasis KKNI } \\
\text { 2. Materi dimasukkan } \\
\text { kedalam website }\end{array}$ \\
\hline
\end{tabular}

Gambar 1. Tahapan Kegiatan Penelitian 
Populasi penelitian ini adalah Jurusan Pendidikan Olahraga. Teknik pengambilan sampel menggunakan purposive random sampling. Dalam penelitian ini pengambilan sampel bertujuan pada mahasiswa dan dosen mata kuliah pencak silat.

Instrumen penelitian yang digunakan meliputi observasi, studi dokumentasi, wawancara, catatan dosen pencak silat, mahasiswa, dan pengurus provinsi persatuan pencak silat Nangroeh Aceh Darussalam serta lembaran observasi. Ada beberapa teknik analisis data yang digunakan antara lain analisis deskriptif dan analisis inferensial. Penyususnan Silabus dan GBPP dilakukan dengan alur kerja penyusunan berbasis Kerangka Kualifikasi Nasional Indonesia (KKNI).

\section{HASIL DAN PEMBAHASAN Analisi Kebutuhan}

Dalam penelitian pengembangan analisi kebutuhan merupakan suatu hal yang pertama dan mendasar yang harus dilakukan karena tahap ini akan diperoleh infoemasi yang akan mendukung hasil penelitian. Pada tahap ini sangat diperlukan informasi akurat yang berhubungan dengan mata kuliah pencak silat. Indentivikasi kebutuhan kurikulum pencak silat adalah kegiatan penulis untuk memperoleh informasi kebutuhan kurikulum pada dosen, dengan memberikan informasi tersebut dapat berupa: mengumpulkan data dari stakeholder, pakar pencak silat, dosen mata kuliah pencak silat, ahli Kerangka Kualifikasi Nasional Indonesia (KKNI), analisis Rencana Program Perkuliahan dan silabus yang digunakan selama ini dalam perkuliahan pencak silat.

Informasi yang telah diperoleh dari hasil analisis kebutuhan terkait dengan proses pembelajaran pencak silat dapat digunakan untuk menganalisis kebutuhan. Untuk memperoleh informasi dilapangan penulis terlebih dahulu melakukan observasi dan wawancara kepada dosen yang mengampu mata kuliah pencak silat. Dari hasil observasi yang dilakukan ditemukan bahwasannya selama ini kurikulum untuk pencak silat sangat terkendala. Selanjutnya penulis melakukan wawancara dengan mahasiswa Prodi Olahraga yang sudah pernah mengambil mata kuliah terkait dengan kebutuhan mereka terhadap kurikulum pencak silat. Dari hasil wawancara dapat disimpulkan bahwa:

1. Kondisi awal mahasiswa

Setelah dilakukan wawancara dengan mahasiswa diperoleh informasi bahwasanya selama ini dalam pembelajaran pencak silat mahasiswa sangat merasa kesulitan dan terkendala dalam hal kurikulum. Tidak adanya kurikulum membuat mahasiswa merasa kesulitan untuk mengulang materi setelah perkuliahan. Buku pencak silat yang bereedar diluaran tidak sesuai dengan apa yang menjadi tuntutan dalam perkuliahan. Dengan diterapkannya Kerangka Kualifikasi Nasional Indonesia (KKNI) menuntut mahasiswa harus benar-benar aktif dalam perkuliahan. Setelah diberlakukannya Kerangka Kualifikasi Nasional Indonesia (KKNI) Prodi olahraga Universitas Samudra mahasiswa dituntut untuk mendalami salah satu cabang olahraga. Mahasiswa yang mengambil pendalaman untuk mata kuliah pencak silat sangat merasa kesulitan pada saat perkuliahan. Sehingga mereka sangat membutuhkan kurikulum yang bisa membantu mereka dalam mengulang materi ataupun untuk mengerjakan tugas-tugas yang diberikan oleh dosen dan bagaimana mereka dituntut antuk bisa menjadi pelatih/guru yanga kompeten dibidangnya. Dari hasil wawancara yang telah dilakukan kepada mahasiswa dapat diambil kesimpulan bahwa mahasiswa Program Studi olahraga yang mengambil mata kuliah pencak silat masih terkendala pada kurikulum yang bisa dijadikan pegangan untuk mengasah kemampuan untuk menjadi pelatih ataupun guru yang nantinya kompeten di bidangnya.

2. Hasil wawancara dengan dosen Kelompok Dosen Bidang Keahlian (KDBK) pencak silat

Dari hasil wawancara dengan dosen KDBK dapat diambil sebuah kesimpulan salah satu yang menjadi kendala tidak tercapainnya semua materi untuk pembelajaran dikarenakan adanya pembagian materi kepada mahasiswa. Dengan adanya Kerangka Kualifikasi Nasional Indonesia (KKNI) ini diharapkan fokus mahasiswa lebih tertuju kepada apa yang menjadi tuntutan dari Kerangka Kualifikasi Nasional Indonesia (KKNI) itu sendiri, sehingga untuk mempersiapkan hal tersebut perlu dilakukan persamaan persepsi baik di dalam penyusunan perangkat pembelajaran maupun penggunaan kurikulum. Wawancara ini dilakukan di kampus yang berbeda, dan yang menjadi kampus pembanding pada penelitian ini adalah dosen-dosen Kelompok Dosen Bidang Keahlian (KDBK) kampus Universitas Negeri Jakarta dan juga dosen pencak kampus Universitas Samudra dimana penelitian dilakukan. Banyak masukan yang di dapat oleh peneliti dari setiap dosen-dosen Kelompok Dosen Bidang Keahlian (KDBK) pencak silat baik dari Universitas Negeri Jakarta maupun dari Universitas Samudra (UNSAM) dan ini akan dijadikan penulis sebagai bahan pertimbangan di dalam pembuatan Rencana Perkuliahan Semester (RPS) mata kuliah pencak silat yang berbasis Kerangka Kualifikasi Nasional Indonesia (KKNI). 
3. Hasil wawancara dengan pelatih pencak silat

Wawancara ini ditujukan kepada pelatih pencak silat yang merupakan alumni pendidikan kepelatihan olahraga ini bertujuan untuk memperkuat analisis masalah. Dari hasil wawancara dapat diambil kesimpulan bahwa pengetahuan yang dimiliki untuk melatih pencak silat masih kurang ketika masih kuliah. Sehingga dengan demikian perlu dilakukan pendalaman materi pada saat perkuliahan maupun pendalaman materi kepelatihan di dalam kurikulum yang akan dikembangkan.

Untuk lebih memperkuat kebutuhan pengembangan kurikulum selanjutnya penulis melakukan wawancara terhadap dosen pengampu mata kuliah, dari hasil wawancara dengan dosen-dosen pencak silat dapat disimpulkan bahwa:

1. Rencana Pembelajaran Semester (RPS) antar dosen belum seragam

2. Kurikulum yang dipergunakan untuk pembelajaran mata kuliah pencak silat belum lengkap

3. Masih adanya perbedaan dalam penyampaian materi dari antar dosen terutama untuk pembelajaran praktek jurus

4. Terbatasnya literatur/buku pendukung untuk penunjang perkuliahan pencak silat

5. Kurangnya persamaan persepsi dari dosen Kelompok Dosen Bidang Keahlian (KDBK) pencak silat

6. Masih adanya perbedaan penilaian dosen terhadap hasil belajar pencak silat mahasiwa

7. Rendahnya pemahaman serta pengetahuan mahasiswa tentang pencak silat khususnya untuk pemahaman gerakan-gerakan jurus yang ada dalam pencak silat dikarenakan terbatasnya buku pegangan yang dapat dijadikan mahasiswa untuk bahan mengulang materi

Setelah dilakukan wawancara selanjutnya dilakukan observasi dan analisis RPP dan silabus pencak silat yang selama ini menjadi pegangan dosen. Dari hasil observasi yang dilakukan dapat disimpulkan bahwa:

1. Kontrak kuliah yang dirancang oleh dosen masih terdapat perbedaan

2. Kurang sesuainya isi silabus dengan RPP

3. Terbatasnya sumber bahan ajar yang dimuat di dalam RPP sehingga menyebabkan mahasiswa untuk mencari sumber belajar yang lain.

4. Belum semua dosen mata kuliah pencak silat menyusun RPP

5. Masih belum dicantumkannya evaluasi pembelajaran pada RPP

6. Tidak mencantumkan buku sumber yang dapat dijadikan acuan bagi mahasiswa

Setelah melakukan wawancara dan observasi dengan dosen dan mahsiswa serta pelatih pencak silat selanjutnya dilakukan wawancara dengan stakeholder dan pakar untuk melihat kebutuhan dalam perkembangan kurikulum pencak silat berbasis Kerangka Kualifikasi Nasional Indonesia (KKNI). Adapun hasil wawancara dengan stakeholder dan pakar tentang kompetensi yang diharapkan:

1. Mahasiswa memahami dasar-dasar pencak silat

2. Mahasiswa memiliki kompetensi untuk menjadi pelatih silat yang kompeten

3. Mahsiswa mengetahui peraturan perwasitan pencak silat

4. Mahasiswa dapat menyusun program latihan yang sesuai dengan tuntutan pencak silat pilihan mahasiswa. Sehingga dosen harus benar-benar memperhatikan kebutuhan mahasiswa sesuai dengan tuntutan Kerangka Kualifikasi Nasional Indonesia (KKNI).

Dengan tersusunya Rencana Perkuliahan Semester (RPS) ini maka akan menjadi langkah awal untuk penyususnan buku pencak silat yang berbasis Kerangka Kualifikasi Nasional Indonesia (KKNI) pada tahun berikutnya. Pada tahap ini RPS yang tersusun merupakan gambaran dari kondisi yang diperlukan dalam mata kuliah pencak silat. Pengembangan produk dilakukan oleh peneliti berdasarkan masukan dari dosen, pelatih dan pakar yang ahli dalam bidangnya. Keahlian tersebut dapat berupa ahli isi (materi) dan ahli pembelajaran (perancang pembelajaran). adalah:

Adapun langkah-langkah penyusunan Rencana Perkuliahan Semester (RPS) pencak silat tersebut

1. Identifikasi Mata Kuliah

Dengan diterapkannya Kerangka Kurikulum Nasional Indonesia (KKNI) perlu dilakukan pengkajian ulang tentang identifikasi mata kuliah pencak silat. Identifikasi dilakukan dikarenakan pada awalnya di pendidikan olahraga UNSAM mahasiswa selain untuk menjadi guru juga harus bisa melatihkan dasar-dasar pencak silat baik di klub sekolah maupun di luar sekolah yang dibina oleh Komite Olahraga Nasional Indonesia (KONI) kabupaten kota. Dengan adanya Kerangka Kurikulum Nasional Indonesia (KKNI) mahasiswa fokus terhadap spesialisasi masing-masing sehingga identifikasi dari mata kuliah perlu dikaji ulang dengan mengembangnkan yang sudah ada dengan Kerangka Kurikulum Nasional Indonesia (KKNI).

2. Capaian Pembelajaran

Capain pembelajaran merupakan hal yang harus disepakati bersama dosen pengampu mata kuliah. Dengan adanya spesialisasi dosen harus menyepakati sejauh mana capaian pembelajaran yang dituntut dan diharapkan dari mahsiswa sesuai Kerangka Kurikulum Nasional Indonesia (KKNI). 


\section{Indikator Capaian Pembelajaran}

Indikator ini merupakan poin-poin yang telah disepakati bersama Focus Group Discussion (FGD) guna mendukung tercapainya pembelajaran. Indikator ini dikembangkan dari indikator yang sudah ada dengan Kerangka Kurikulum Nasional Indonesia (KKNI).

4. Bahan / Materi Kajian

Dari analisis kebutuhan yang telah dilakukan terhadap mahasiswa dan dosen ditemukan dilapangan bahwa adanya perbedaan materi di antara dosen. Dengan adanya Rencana Perkuliahan Semester (RPS) dan draf kurikulum pencak silat berbasis Kerangka Kurikulum Nasional Indonesia (KKNI) ini nantinya akan memberikan keseragaman materi kepada masing-masing dosen pengampu mata kuliah pencak silat. Karena di dalam pembelajaran materi yang disampaikan merupakan hal terpenting untuk mencapai tujuan pembelajaran. Dalam materi ini akan dikembangkan sesuai dengan penunjang untuk kuliahb spesialisasi atau lanjutan.

5. Sumber Belajar

Keseragaman sumber belajar dalam Kerangka Kurikulum Nasional Indonesia (KKNI) perlu dilakukan mengingat tuntutan yang harus di capai mahsiswa. Keseragaman sumber belajar ini harus mendukung kemapuan mahasiswa untuk menjadi guru yang handal di bidang masing-masing yaitu pencak silat. Materi pembelajaran meliputi materi pokok dan uraian materi pokok.

Dalam pengembangan Rencana Perkuliahan Semester (RPS) ini dilakukan juga pengembangan terhadap kontrak perkuliahan. Kontrak perkuliahan merupakan kesepakatan dosen dan mahasiswa mengenai berbagai aspek perkuliahan yang dilakukan di awal perkuliahan. Adapun deskripsi dalam membuat kontak kuliah sesuian dengan Kerangka Kurikulum Nasional Indonesia (KKNI) adalah sebagi berikut: Identifikasi Mata Kuliah, Deskripsi Mata Kuliah dan Pernyataan kesepakatan yang mencakup semua perjanjian dosen dengan mahasiswa pada saat perkuliahan berlangsung.

\section{Uji Coba Kelompok Kecil}

Setelah draf pengembangan Rencana Perkuliahan Semester (RPS), kontrak kuliah, serta draf materi bahan ajar pencak silat selesai dikerjakan, selanjutnya dilakukan uji coba dengan fokus group untuk melakukan revisi serta masukan-masukan bahan draf yang sudah dikerjakan. Uji coba dilakukan dengan tujuan untuk mendapatkan data, informasi, dan masukan mengenai kelayakan Rencana Perkuliahan Semester (RPS), kontrak kuliah dari segi kelayakan materi dan sesuai dengan tagihan Kerangka Kualifikasi Nasional Indonesia (KKNI).

Ruang Lingkup Kegiatan, yaitu uji coba Rencana Perkuliahan Semester (RPS), kontrak kuliah, mencakup aspek korelasi dengan kurikulum, rencana pembelajaran, fungsional dan bermakna, serta penyajian menarik dengan langkah kegiatan pada tahap ini adalah Presentasi bahan ajar yaitu Presentasi kurikulum, kontrak kuliah merupakan penjelasan singkat tentang Rencana Perkuliahan Semester (RPS) dan kontrak kuliah dan penjelasan tata cara mengkritisi dan memberi masukan terhadap Rencana Perkuliahan Semester (RPS) dan kontrak kuliah yang telah disusun. Dan diskusi, yaitu setelah dilakukan presentasi tentang draf kurikulum yang telah disusun selanjutnya dilakukan FGD dengan dosen pencak silat sekaligus sebagai ahli pencak silat.

Adapun masukan dalam uji coba melalui kelompok besar melalui diskusi adalah :

Tabel 1. FGD Kelompok Besar

\begin{tabular}{|c|c|c|c|}
\hline No & Nama & Jabatan & Masukan \\
\hline 1 & Johaidah Mistar, M.Pd & Dosen & Keterampilan dasar pencak silat harus dimuat duluan dalam RPS \\
\hline 2 & Basyaruddin Acha, M.Pd & Dosen & $\begin{array}{l}\text { Untuk pokok bahasan keterampilan teknik harus di muat mulai dari } \\
\text { tendangan, pukulan, elakan dan tangkisan }\end{array}$ \\
\hline 3 & Dr. Johansyah Lbs, M.Pd & Dosen & Dilakukan pengkajian tentang susunan materi pada setiap pertemuan \\
\hline 4 & Dr. Sri Nuraini, M.Pd & Dosen & $\begin{array}{l}\text { Dalam penyusunan materi dikaitkan dengan pembinaan kondisi fisik } \\
\text { untuk cabang olahraga pencak silat }\end{array}$ \\
\hline 5 & Dr. Widiastuti, M.Pd & Dosen & $\begin{array}{l}\text { Mencantumkan materi faktor-faktor yang meningkatkan kemampuan } \\
\text { teknik pencak silat }\end{array}$ \\
\hline 6 & Herwandi, M.Pd & Wasit & $\begin{array}{l}\text { Memasukkan materi tentang perwasitan pencak silat sesuai dengan } \\
\text { yang ditetapkan IPSI }\end{array}$ \\
\hline 7 & Ismed SW & Pelatih & $\begin{array}{l}\text { Mencantumkan materi yang mendukung mahasiswa untuk kepelatihan } \\
\text { pencak silat }\end{array}$ \\
\hline 8 & Beni Arifin, S.Pd & Pelatih & $\begin{array}{l}\text { Mencantumkan materi yang mendukung kemampuan mahasiswa } \\
\text { untuk kepelatihan pencak silat }\end{array}$ \\
\hline
\end{tabular}




\section{Revisi Produk Kedua}

Hasil dari diskusi yang dilakukan pada kelompok besar yang melibatkan 8 orang masing-masing sudah memberikan masukan untuk kesempurnaan kurikulum pencak silat. Dari masukan yang telah disampaikan selanjutnya dilakukan perbaikan untuk kesempurnaan produk sesuai dengan masukanmasukan tersebut dengan harapan Rencana Perkuliahan Semester (RPS) dan kontrak kuliah sudah dapat dijadikan acuan dan digunakan untuk mata kuliah pencak silat.

Pengembangan perangkat pembelajaran seperti Rencana Perkuliahan Semester (RPS) dan kontrak kuliah merupakan komponen yang harus diperhatikan oleh dosen dalam perkuliahan. Diterapkannya Kerangka Kualifikasi Nasional Indonesia (KKNI) membuat prodi harus menyesuaikan perkuliahan sesuai dengan tuntutan Kerangka Kualifikasi Nasional Indonesia (KKNI). Adanya perubahan tersebut membuat dosen harus menyesuaikan perangkat pembelajaran sesuai dengan Kerangka Kualifikasi Nasional Indonesia (KKNI). Adanya perubahan tersebut dosen pencak silat pada prosi olahraga FKIP Unsam mealakukan pengembangan kurikulum pencak silat dengan berbasis Kerangka Kualifikasi Nasional Indonesia (KKNI). Pengembangan ini dirasa penting dikarenakan untuk menunjang perkuliahan yang berbasi Kerangka Kualifikasi Nasional Indonesia (KKNI) sehingga outcome mahsiswa prodi olahraga khususnya untuk mahasiswa spesialisasi pencak silat mempunyai kemapuan dalam hal melatih pencak silat. Untuk RPS adalah perangkat rencana pembelajaran pada suatu dan/atau kelompok mata kuliah/tema tertentu yang mencakup standar kompetensi, kompetensi dasar, materi pokok/ pembelajaran, kegiatan pembelajaran , indikator, penilaian, alokasi waktu, dan sumber/bahan/alat belajar (PP No 19 Tahun 2005 Pasal 20 ).

Dalam penyususnan draf kurikulum pencak silat dilakukan melalui analisis kebutuhan yang dilakukan melalui observasi terhadap dosen dan mahasiswa. Dari hasil observasi tersebut selanjutnya tim peneliti melakukan langkah awal untuk melakukan penelitian dan laporan hasil penelitian. Pengembangan kurikulum yang telah dilakukan masih dalam bentuk Rencana Perkuliahan Semester (RPS). Dengan adanya pengembangan Rencana Perkuliahan Semester (RPS) ini nantinya akan dilakukan pengembangan bahan ajar pencak silat pada tahun berikutnya.

Merancang Rencana Perkuliahan Semester (RPS) dan kontrak perkuliahan merupakan kegiatan dosen yang harus dilakukan dosen pada setiap semesternya. Pada dasarnya yang dimaksud dengan kontrak perkuliahan atau kontrak pembelajaran adalah rancangan perkuliahan yang disepakati bersam oleh dosen dan mahasiswa. Sebagaimana halnya suatu kesepakatan tentu pelaksanaannya dilaksanakan sebelum semester atau awal semester, tepatnya pada pilihan mahasiswa sehingga dosen benar-benar memperhatikan kebutuhan mahasiswa sesuai dengan tuntutan Kerangka Kualifikasi Nasional Indonesia (KKNI).

\section{SIMPULAN}

Berdasarkan hasil penelitian dan analisis kebutuhan yang telah dilakukan sejauh ini maka dapat disimpulkan bahwa hasil dalam hal pembelajaran pencak silat mahasiswa Prodi Olahraga masih terkendala dalam hal penunjang perkuliahan berupa kurikulum. Pengembangan kurikulum tersebut dirasa perlu agar kompetensi mahasiswa Pekan Olah Raga (POR) khususnya yang mengambil spesialisasi pencak silat dapat tercapai. Hasil wawancara dengan Kelompok Dosen Bidang Keahlian (KDBK) pencak silat dari hasil wawancara dengan dosen Kelompok Dosen Bidang Keahlian (KDBK) dapat diambil sebuah kesimpulan bahwasannya dalam penyususnan kurikulum pencak silat perlu dilakukan persamaan persepsi agar sehingga perangkat pembelajaran dan kurikulum bisa terfokus sesuai dengan tuntutan Kerangka Kualifikasi Nasional Indonesia (KKNI). Pengembangan kurikulum pencak silat dilakukan melalui analisis kebutuhan, melakukan perencanaan, mengembangkan produk, uji kelompok kecil dan uji kelompok besar.

\section{DAFTAR PUSTAKA}

Ali, M. (2010). Metodologi dan Aplikasi Riset Pendidikan. Bandung: Pustaka Cendikia Utama.

Anonim, (2010) Strategi Sanitasi Kota Langsa. Program Percepatan Pembangunan Sanitasi Permukiman - PPSP-2010

Anonim. Undang-Undang No. 24 Tahun 2007. Tentang Penanggulangan Bencana

Anwar, E. (2015) Banjir Landa Sebagian Gampong di Kota Langsa. Lintas Nasional (on line) http://www.lintasnasional.com/2015/09/30/banjir-landa-sebagian-gampong-di-kota-langsa/ diakses pada 17 Mei 2017

Badan Penanggulangan Bencana Daerah Kota Langsa (2015)

Badan Penanggulangan Bencana Aceh (2015)

Bakri, Z. (2017) Puluhan Rumah di Langsa Terendam Banjir.Go Aceh.co (on line) https://www.goaceh.co/berita/baca/2017/05/19/puluhan-rumah-di-langsa-terendambanjir\#sthash.Jto8l442.dpbs diakses 17 Mei 2017

Creswell, J.W. (2008). Educational Research: Planning, Conducting, and Evaluating Quantitative and Qualitative Research. New Jersey: Pearson Education Inc. 
Suandi Selian \& Dodi Irwansyah. Pengembangan Kurikulum Pencak Silat Berbasis Kerangka Kualifikasi Nasional Indonesia

Emily Y.Y. Chan. (2012). Preliminary Findings on Urban Disaster Risk Literacy and Preparedness in a Chinese Community (on line) https://wfpha.confex.com/wfpha/2012/webprogram/Paper9563.html diakses pada 17 Mei 2017.

Emzir. (2012). Metodologi Penelitian Pendidikan: Kuantitatif dan Kualitatif. Jakarta: Rajawali Pers.

Priyowidodo, G. \& Luik, J.E. (2013). Literasi Mitigasi Bencana Tsunamai untuk Masyarakat Pesisir di Kabupaten Pacitan Jawa Timur. Jurnal Ekotrans Vol.13 No. 1 Januari 2013, hlm 47-61.

Immadudina, A. (2011). Zonasi Risiko Bencana Banjir Akibat Sea Level Rise. Surabaya: Institut Teknologi Sepuluh Nopember

Masyhuri, \& Zainuddin, M. (2008). Metodologi Penelitian Pendekatan Praktis dan Aplikatif. Bandung: PT Refika Aditama Marlyono, dkk (2010) Pengaruh Literasi Informasi Bencana Terhadap Kesiapsiagaan Masyarakat Dalam Menghadapi Bencana Di Provinsi Jawa Barat. Jurnal Pendidikan Geografi, Volume 16, Nomor 2, Oktober 2016

McMillan, J.H. (2012). Educational Research: Fundamentals for The Consumer. Sixth Edition. Virginia: Pearson.

Peraturan Pemerintah Republik Indonesia Nomor 64 Tahun 2010 Tentang Mitigasi Bencana Di Wilayah Pesisir Dan Pulau-Pulau Kecil 